This item was submitted to Loughborough's Research Repository by the author.

Items in Figshare are protected by copyright, with all rights reserved, unless otherwise indicated.

\title{
Bricolage and informal businesses: Young entrepreneurs in the mobile telephony sector in Accra, Ghana
}

PLEASE CITE THE PUBLISHED VERSION

https://doi.org/10.1016/j.futures.2019.102487

\section{PUBLISHER}

Elsevier BV

VERSION

AM (Accepted Manuscript)

\section{PUBLISHER STATEMENT}

This paper was accepted for publication in the journal Futures and the definitive published version is available at https://doi.org/10.1016/j.futures.2019.102487.

\section{LICENCE}

CC BY-NC-ND 4.0

\section{REPOSITORY RECORD}

Afutu-Kotey, Robert Lawrence, and Katherine V. Gough. 2019. "Bricolage and Informal Businesses: Young Entrepreneurs in the Mobile Telephony Sector in Accra, Ghana”. Loughborough University. https://hdl.handle.net/2134/11294798.v1. 


\title{
Bricolage and informal businesses: Young entrepreneurs in the mobile telephony sector in Accra, Ghana
}

Robert Lawrence Afutu-Kotey

School of Continuing and Distance Education, University of Ghana

rafutu-kotey@ug.edu.gh

Katherine V. Gough

Department of Geography

Loughborough University

K.V.Gough@lboro.ac.uk

Futures (2019) doi:https://doi.org/10.1016/j.futures.2019.102487

\begin{abstract}
The concept of bricolage has primarily been used in exploring how entrepreneurs in the formal sector, in addition to social entrepreneurs, mobilise resources in developing their businesses. Little is known, however, about the bricolage experiences of young informal entrepreneurs in the rapidly changing, technologically driven mobile telephony sector. Drawing on qualitative field research with young people involved in informal support services in the mobile telephony sector in Accra, Ghana, the paper reveals the existence of various kinds of bricolage processes employed in the running and sustenance of their businesses. The findings show evidence of young people switching from one business to another, engaging in business diversification, utilising pre-existing skills, and employing bottom-up approaches through their social networks in mobilising resources - all of which relate to bricolage processes of improvisation, 'making do' and refusing to be constrained by limitations in the resource environment. Although young people are shown to utilise strategies of self-support and ingenuity in running and sustaining their businesses, the paper concludes by calling for a more supportive institutional framework in order to propel the businesses of young people into the future.
\end{abstract}

Key words: Bricolage, resource mobilisation, informal economy, mobile phone, Ghana 


\section{Introduction}

The adoption and geographical spread of mobile phones during the past decade has been phenomenal in Sub-Saharan Africa. According to the International Telecommunication Union, Africa had 23.5 mobile cellular subscriptions per 100 inhabitants in 2007, which more than trebled to 77.8 per 100 inhabitants by 2017. A significant body of literature has emerged highlighting the varied uses to which people put their mobile phones, including as a business tool (Komunte, 2015), to support student learning (Kuznekoff \& Titsworth, 2013; Kuznekoff, Munz, \& Titsworth, 2015; Porter et al., 2016), and to aid mobility (Porter et al. 2012; Porter 2015). Attention has also been devoted to the emotional attachment people have to their phones (Hoffner, Lee, \& Park, 2016; Meschtscherjakov, Wilfinger, \& Tscheligi, 2014; Vincent, 2006) and the developmental and security implications of mobile phones (Asongu \& Nwachukwu, 2016; Ben-Asher et al., 2011; Donner, 2015; de Reuver et al., 2011). Despite this extensive research, limited attention has been paid to the entrepreneurial support services within the mobile telephony sector, how these fare over time and their prospects for the future.

The mobile telephony support sector in Ghana is dominated by young people operating a wide range of informal businesses including: the sale of mobile phones, accessories and airtime; the repair of mobile phones and other technical support; and mobile money transfer services (Afutu-Kotey, 2016; Afutu-Kotey, Gough, \& Yankson, 2017). Establishing and running such businesses requires crucial resources (Ray, Barney, \& Muhanna, 2004), which is especially challenging in a Sub-Saharan African context due to the paucity of resources and lack of institutional support (Langevang, Gough, \& Namatovu, 2016). As the mobile telephony sector changes rapidly with frequent technological innovations, it is important to understand how informal entrepreneurs operating in resource constrained environments manage to mobilise resources to sustain, grow and diversify their businesses as they confront the future. Drawing on longitudinal research on support services to the mobile telephony sector in Accra, Ghana, this paper addresses the following questions: How do entrepreneurs establish their businesses amid resource constraints? How do they survive in such a rapidly changing, technologically driven sector? How do they mobilise resources to sustain their businesses? Understanding these issues is important as the sustainability and future of businesses, including in a Sub-Saharan African context, remains crucial for the individual entrepreneur and society at large (Fuller, 2003; Randerson, Dossena, \& Fayolle, 2016). 
Following this introduction, the paper is divided into seven sections. The next section discusses the concepts of informal entrepreneurship, resources and bricolage, which frame the paper conceptually. The methodological approach is then presented before the findings are divided into three sections: business trajectories, responses to changes, and mobilising resources. Bricolage and possible futures for young people are further discussed before the conclusion summarises the findings, drawing out their wider significance and indicates some policy implications.

\section{Informal entrepreneurship, resources and bricolage}

Economic restructuring and the transformation of labour markets have resulted in high levels of unemployment, especially among 'youth' ', in Africa, Asia, and Latin America (Gough, Langevang, \& Owusu, 2013). Consequently, young people across the global South are involved in a broad range of business activities including vending goods - such as mobile phone prepaid cards, food and beverages - and providing services - such as charging mobile phones, car washing and braiding hair (Gough \& Langevang, 2016; Hajdu et al., 2013; Kristensen \& Birch-Thomsen, 2013; Thorsen, 2013). In line with Steyaert and Katz's (2004) notion of entrepreneurship as an 'everyday societal phenomenon', such activities are increasingly seen as being entrepreneurial, with entrepreneurship defined as 'spotting and seizing an opportunity to establish a business and, in the process, taking risks and managing the available resources creatively' (Gough \& Langevang, 2016, p. 4). Entrepreneurship is thus an activity that 'ordinary' individuals engage in, not one restricted to a few select people. Although entrepreneurship discourses have been underpinned by neoliberal market values of competition, efficiency, self-reliance and self-governance (Dolan, 2012), they can also be seen as being indicative of 'traditional', non-market-based principles of shrewdness and thrift (Jeffrey \& Young, 2014).

Early studies of the informal economy, which were dominated by the structuralist school of thought, depicted it as absorbing surplus labour in subordinated economic units that served the competitiveness of larger firms (Castells \& Portes, 1989); from this perspective, workers engage in informal work out of economic necessity. During recent decades, scholars subscribing to legalist and neo-liberal schools of thought have challenged this idea

\footnotetext{
${ }^{1}$ The UN definition of youth is people aged between 15 and 24 but in a Sub-Saharan African context the age range of 15 to 35 is commonly used.
} 
(Langevang, 2016), reconceptualising informal workers as people 'displaying entrepreneurial attributes, traits and qualities' (Gurtoo \& Williams, 2009, p. 57). Conceptualising business owners in the informal economy as entrepreneurs has been endorsed by international organisations, such as the World Bank and the ILO, which claim that informal entrepreneurs demonstrate acumen, creativity, dynamism, and innovation (Gurtoo \& Williams, 2009). This is essential in Sub-Saharan Africa, where the informal economy was estimated by the Organisation for Economic Co-operation and Development to already contribute 55 percent of GDP and 80 percent of employment in 2012. Access to scarce resources, widely defined as "the tangible and intangible assets firms use to develop and implement their strategies" (Ray et al., 2004, p. 24), remains critical to the establishment and growth of informal businesses. Although most entrepreneurs operate under conditions of resource paucity (Baker \& Nelson, 2005), informal businesses are particularly constrained by resource availability (Holt \& Littlewood, 2017) as they mostly do not have the means to afford standard resources. In order to understand how businesses, navigate the challenges of resource constraints, the concept of bricolage has been shown to be useful in a range of contexts (Baker \& Nelson, 2005; Desa \& Basu, 2013; Langevang et al., 2016; Senyard et al., 2014; Witell et al., 2017).

The concept of bricolage was widely popularised by Baker and Nelson (2005) but can be traced back to the work of Levi Strauss (1967, p. 17) who described bricolage as "always to make do with "whatever is at hand." One of the most widely cited definitions is Baker and Nelson's (2005, p. 333) “making do by applying combinations of the resources at hand to new problems and opportunities". Bricolage can thus refer to the "combination and reuse of resources for different applications than those for which they were originally intended or used" (Baker and Nelson, 2005, p. 335). Similarly, Gibbert, Hoegl, and Välikangas (2007) define bricolage as having the capabilities to discern and utilise resources at the periphery in order to gain innovative outcomes, while Salunke, Weerawardena and McColl-Kennedy (2013) see bricolage as the capacity to recombine resources under conditions of resource constraints or when having to work with limited resources to generate greater value for clients. Key to all the various definitions are the themes of making do with resources at hand, improvisation and refusal to be constrained by environmental limitations (Baker, Miner, \& Eesley, 2003; Baker \& Nelson, 2005; Di Domenico, Haugh, \& Tracey, 2010; Gibbert, Hoegl, \& Välikangas, 2007; Linna, 2013; Salunke, Weerawardena, \& McColl-Kennedy, 2013; Weick, 1993). In this paper we draw on the 'making do' with resources at hand approach, which highlights combining existing resources for new purposes while creating value by 
using the resources at hand (Di Domenico, Haugh, \& Tracey, 2010). We also pay close attention to bricolage as improvisation and refusal to be constrained by resource availability. Through improvisation, individuals involved in bricolage adapt standard ways of working and respond to changing opportunities, while refusal to be constrained by resources depicts how bricoleurs try out different solutions to overcome limitations imposed by the institutional/political settings and the available resource environments (Di Domenico, Haugh, $\&$ Tracey, 2010). We employ these conceptualisations of bricolage to explore the ways in which young entrepreneurs in the mobile telephony sector mobilise resources in running and sustaining their businesses going into the future.

Two perspectives stand out from the research on bricolage in relation to entrepreneurs. One focusses on addressing the opportunities and problems that using existing unappreciated or superfluous resources, which are mostly available for free or at a low cost, presents (Desa \& Basu, 2013). Through bricolage, small businesses are accorded the opportunity to attain their goals with the barest minimum of resources at their disposal. Such businesses, however, more often than not engage in bricolage because they do not have the means to afford the cost of standard resources. Bricolage, therefore, becomes essential for small businesses leading to the idea of 'necessity based' bricolage (Duymedjian \& Rüling, 2010). A second angle is the way some businesses are able to utilise the potential of superfluous unappreciated resources in a much more creative way in value creation (Desa \& Basu, 2013). Through bricolage, businesses are able to employ discarded resources to create new products or ideas. This form of bricolage has been referred to as 'ideational bricolage', where businesses take advantage of existing values that discarded resources present (Carstensen, 2011; Desa \& Basu, 2013). The bricolage process, therefore, helps to mitigate conditions of resource constraint by enabling businesses to develop new values, ideas or innovations that contribute to their expansion (Desa \& Basu, 2013). In the case of the mobile telephony sector, it is more the former perspective that is relevant, though in line with Langevang, Namatovu and Dawa (2012), we take exception to the idea that entrepreneurs can be simplistically divided into opportunity and necessity entrepreneurs.

Many studies have observed positive bricolage outcomes especially with respect to the growth of firms or entities and innovativeness (Garud \& Karnoe, 2003; Baker \& Nelson, 2005), with some reporting relatively better outcomes for bricoleur firms compared with their well-resourced counterparts (Gibbert, Hoegl, \& Välikangas, 2007; Senyard et al., 2014). 
Other studies, however, have observed that the bricolage process produces lower or inferior quality (Garud \& Karnoe, 2003) or ‘just good enough' (Berchetti \& Hulsink (2006) outcomes. Lanzara (1999: 347) argued that, "bricolage is usually associated with second best solutions, maladaption, imperfection, inefficiency, incompleteness, slowness" and under circumstances where "the outcomes of it are hybrid, imperfect, transient artifacts." The duopolistic views on bricolage outcomes highlight the importance of studying the experiences of young entrepreneurs operating in the resource constrained informal mobile telephony sector.

The bricolage process has been used extensively to explore resource mobilisation initiatives among commercial entities, especially in the formal sector (An et al., 2018; Baker et al., 2003; Baker \& Nelson, 2005; Salunke, Weerawardena, \& McColl-Kennedy, 2013), while emerging literature has given cognisance to bricolage in the field of social entrepreneurship (Desa, 2012; Desa \& Basu, 2013; Di Domenico, Haugh, \& Tracey, 2010; Langevang \& Namatovu, 2019). Little attention, however, has been paid to bricolage processes among informal economy entrepreneurs operating within resource constrained environments. One exception is Holt and Littlewood's (2017) study of waste livelihoods among the poor in Kenya, which observed various dimensions of bricolage including improvisation, making do and recombining resources, showing how the nature of bricolage and the bricoleur agent varies depending on the resources used. Although this study provides a good understanding of the processes of bricolage in the area of waste livelihoods in a Sub-Saharan African context, little is known about the bricolage experiences of informal entrepreneurs working in the rapidly changing, technologically driven mobile telephony sector in Sub-Saharan Africa. This paper aims to fill this gap by exploring the lived experiences of informal mobile telephony entrepreneurs in Accra, Ghana. By paying attention to the resources they rely upon to evolve their businesses in a rapidly changing market, we demonstrate how the concept of bricolage is highly relevant in such contexts.

\section{Methodology}

This paper is based on fieldwork conducted in Accra with young entrepreneurs operating businesses in the mobile telephony sector over the period 2011 to 2013, with repeat interviews conducted in 2017. A qualitative multi-method approach was adopted to explore the lived experiences and businesses of young entrepreneurs in the mobile telephony sector. The first round of data collection in 2011 involved a mapping exercise of localities in Accra 
with a concentration of mobile telephony businesses. Resulting from this mapping exercise, five study localities were selected to represent the diversity of mobile telephony businesses: Kwame Nkrumah Circle, Madina, Tema Lorry Station, Kaneshie Station and the LegonMadina road (see FIGURE 1).

Figure 1: Map of the Greater Accra Metropolitan Area showing study localities



Source: RSGIS Lab, University of Ghana

Following the mapping exercise, life trajectory interviews with 11 young people operating various informal mobile telephony businesses in the study localities were conducted. ${ }^{2}$ Repeat interviews, lasting 45 minutes on average, were carried out on a quarterly basis over a threeyear period from 2011 to 2013. These interviews focussed on the young people's life courses paying attention to how their businesses have changed over time and the key resources they have drawn on to sustain their businesses over the years. In addition, biographical interviews were conducted with 25 young people (two-thirds male and one-third female) operating different mobile telephony businesses in the study localities in 2012, lasting 50 to 70 minutes.

\footnotetext{
${ }^{2}$ The life trajectory interviews in 2012/2013 started with 15 participants - three dropped out during the process and one unfortunately died.
} 
The respondents ranged in age from 21 to 33 years with an average age of 25 . These interviews focused on the young people's lived experiences, with attention given to their life before and after starting a business in the mobile telephony sector.

Following a gap of four to five years, we decided to try to trace these 36 young people to discover how their businesses and lives had evolved. Out of the 11 respondents who participated in the life trajectory interviews, we were able to re-interview eight; two could not be traced and one had taken a temporary break from running her business following childbirth. Out of the 25 young people who participated in the biographical interviews, repeat interviews were conducted with 20; regarding the remaining five, three could not be traced, while one had quit the business to further his education and another had taken a temporary break due to childbirth. Consequently, a total of 28 follow-up interviews were conducted in 2017, of which 7 were with females (see TABLE 1). The age of the young people interviewed ranged from 25 to 38, with an average of 30 years. Fourteen of these had attained a Senior High School qualification, 10 had completed Junior High School and two have a tertiary qualification. ${ }^{3}$ The interviews focussed on discovering how the life course of the operators had evolved, the current state of their businesses, the key resources they were drawing upon, and how they had sustained their businesses over the years.

All the interviews were conducted at the business premises of the young people and were audio recorded after obtaining informed consent. The recordings were transcribed verbatim and several readings of the text conducted in order to get a good understanding of the data before the analysis, which was done manually using inductive themes and codes depicting the nature of bricolage processes - 'making do', improvisation and refusing to be constrained by lack of resources. ${ }^{4}$

\footnotetext{
${ }^{3}$ The educational qualification of respondents did not differ between the two interview periods.

${ }^{4}$ Pseudonyms have been used in the paper in order to protect the anonymity of respondents.
} 
Table 1 Characteristics of respondents traced

\begin{tabular}{|c|c|c|c|c|c|}
\hline Name & Sex & Age & $\begin{array}{l}\text { Level of } \\
\text { education }\end{array}$ & Main business (2011) & Main business (2017) \\
\hline Chub & Male & 33 & SHS & Battery recharging & Accessories \\
\hline Boakye & Male & 30 & SHS & Repairer & Accessories \\
\hline Frank & Male & 30 & SHS & Battery recharging & Accessories \\
\hline John & Male & 30 & SHS & Accessories & Accessories \\
\hline Kwesi & Male & 29 & JHS & Accessories & Accessories \\
\hline James & Male & 38 & Tertiary & Airtime & Airtime \\
\hline Peace & Female & 29 & No qualification & Airtime & Airtime \\
\hline Efe & Female & 25 & SHS & Airtime & Airtime \\
\hline Prince & Male & 29 & JHS & Airtime & Mobile money \\
\hline Ama & Female & 28 & SHS & Accessories & Mobile money \\
\hline Akua & Female & 33 & SHS & Airtime & Mobile money \\
\hline Innocent & Male & 31 & SHS & Airtime & Mobile money \\
\hline Kelly & Female & 34 & SHS & Airtime & Mobile money \\
\hline Adjoa & Female & 28 & SHS & Airtime & Mobile money \\
\hline Peter & Male & 25 & JHS & Airtime & Mobile money/Airtime \\
\hline Naana & Female & 28 & SHS & Airtime & Mobile money/Airtime \\
\hline Fausty & Female & 28 & JHS & Airtime & Mobile money/Airtime \\
\hline Dago & Male & 32 & JHS & Airtime & Mobile money/Airtime \\
\hline Sam & Male & 26 & JHS & Phone sales & Phone sales \\
\hline Elvis & Male & 32 & SHS & Phone sales & Phone sales \\
\hline Kofi & Male & 33 & No qualification & Phone sales & Phone sales \\
\hline Fred & Male & 30 & SHS & Phone sales & Phone sales \\
\hline Dave & Male & 35 & JHS & Battery recharging & Phone sales \\
\hline Sack & Male & 34 & SHS & Phone sales & Phone sales/Accessories \\
\hline Martins & Male & 29 & JHS & Repairer & Repairer \\
\hline Kobina & Male & 33 & JHS & Repairer & Repairer \\
\hline Okai & Male & 33 & Tertiary & Repairer & Repairer \\
\hline Michael & Male & 29 & JHS & Repairer & Repairer/Accessories \\
\hline
\end{tabular}

Source: Compiled from interviews 2011 and 2017

\section{Changes in the mobile telephony businesses}

At the time of the initial data collection in 2011, the most dominant business activities in the mobile telephony sector were: sale of mobile phones and mobile phone accessories, airtime sales, mobile phone repairs and technical support. These activities are presented individually in this section, drawing on the longitudinal primary data collected to show how they have evolved in differing ways over time. 


\section{Sale of mobile phones and accessories}

The mobile phone sales business has expanded over the years with the growing desire among the Ghanaian populace for mobile phones. Total mobile telephony voice subscription in Ghana increased from approximately 5 million in 2006 to almost 41 million in 2018 (National Communications Authority, 2018). With a total population estimated at 30 million, this highlights how it is not uncommon to have more than one phone in Ghana; this is both a matter of prestige and in order to reduce costs, since it is cheaper to ring to a phone number on the same network. Moreover, as data packages and charges differ between networks, people prefer to use specific networks for different purposes to reduce the cost.

Alongside the growing number of Ghanaians owning mobile phones, the number of entrepreneurs who have established phone sales businesses has expanded to meet the rising demand (Afutu-Kotey, 2013). According to our respondents, initially these businesses stemmed from the activities of young university students and individuals on business trips who travelled to Europe and the United States and brought back with them both used and new phones. Such businesses have remained a male dominated activity with a heavy concentration of sales taking place in the Kwame Nkrumah Circle Tip-Toe area of Accra and Madina Zongo (see FIGURE 1). The most notable change identified in such businesses between 2013 and 2017 was the increasing proportion of new and technologically sophisticated phones being sold, relative to the sale of used phones that used to dominate the market.

The mobile phone accessories business comprises the sale of phone accessories and replacement parts, such as chargers, earpieces, screen protectors, and phone covers among others. Whilst some mobile phone sellers also sell accessories, our mapping exercise revealed that there are many businesses specialising solely in the sale of accessories. Such businesses are also a male dominated activity. Although the precise items being sold have evolved over the years, the nature of the business has not seen any major changes.

\section{Sale of airtime}

For most of the mobile telephony evolution in Ghana, pre-paid customers have outnumbered post-paid customers, although the latter were in the majority at the initial stages when only the elite could afford a mobile phone (Afutu-Kotey, 2013). As pre-paid customers must purchase airtime, this opened a window of opportunity to primarily young people who started airtime businesses to meet this demand. The airtime business is a female dominated activity, 
which mostly takes place along major or traffic intense roads, in residential areas, and in other business spaces such as markets and transport terminals.

The airtime business intensified initially with the increase in the number of people with mobile phones, resulting in higher demand for the scratch cards to upload airtime. In recent years, however, those working in the trade reported that the airtime business has undergone significant changes as the use of scratch cards to upload airtime on phones has reduced significantly, being replaced by electronic means of uploading airtime through mobile money services. The drive for so-called 'e-airtime' has been heavily influenced by telephony operators who have been offering bonuses to people who purchase airtime electronically. As the proportion of people who recharge their phones electronically has increased, the number of people in the airtime trade has reduced substantially (see TABLE 1), as is readily visible on the streets of Accra, which has gender implications as this was the one sector dominated by women.

\section{Phone repairs and technical support}

The mobile phone repairs and technical support sector comprises businesses that fix or replace old mobile phone parts, upload songs onto phones, and recharge phone batteries. Our data revealed that the repair business is dominated by young males who typically were previously involved in the repair of watches, radio and other electronic devices. With the emergence of the mobile phone, and the strong desire of many people to fix rather than replace broken phones, these young people recounted how they saw a more profitable niche which they moved into. Although the technology of phones is constantly changing, resulting in entrepreneurs having to learn new skills, the nature of the phone repair business has not changed significantly over the past half-decade.

Some entrepreneurial young men engage in the recharging of mobile phone batteries at transport terminals and markets, a service that is popular among market women, drivers and their assistants, and other travellers who need to recharge their phones. This was especially important for individuals who did not have, or had an unreliable, electricity supply in their homes. With the increasing access to and reliability of the electricity supply in recent years (Amankwaa, 2017; Eshun \& Amoako-Tuffour, 2016), most people can recharge their phones at home or even use a source of electricity, either at the market or transport terminals. Consequently, there has been a reduction in the demand for phone recharging and a 
corresponding fall in the number of such businesses. The respondents who were still running mobile phone charging businesses complained that the business is not as lucrative as it used to be.

\section{Mobile money services}

The most striking change in the mobile telephony sector over the past decade is the emergence of mobile money businesses (see TABLE 1), which use mobile phones in conducting financial transactions, such as transfer of airtime, payment of bills and transfer of money between individuals (Ake \& Mbiti, 2010). Over the past few years, a major technological innovation has resulted in the introduction of an electronic payment system via network operators using a mobile money payment platform. This system enables individuals to top-up their mobile phones through mobile money platforms. Alongside the bonus they receive by topping up in this manner, there is also the greater convenience of electronic topups, which has made it more attractive than scratch cards. As our interviews revealed, the mobile money businesses tend to be run by both men and women operating from numerous locations, such as residential areas, transport terminals and bus stations, and other designated business spaces including markets.

\section{Entrepreneurs' responses to the changing sector using bricolage}

In this section we examine the ways in which entrepreneurs working in the various support services of the mobile telephony sector utilise various forms of bricolage in responding to the changes confronting them in their attempts to sustain and grow their businesses in the context of limited resources. As Ligthelm (2010) has argued, the ability of entrepreneurs to adapt to changing environmental circumstances is an important attribute in the sustenance of enterprises in competitive or challenging business environments. Three key strategies are presented: switching business, diversifying business, and skills acquisition.

\section{Switching business}

By switching businesses, the young entrepreneurs engage in bricolage through improvisation (Di Domenico, Haugh, \& Tracey, 2010) by creatively switching from one business activity to another in order to survive the challenging and fast changing business environment in which they operate. The operators who specialised in selling airtime are those who have had to improvise by creatively switching out of their business with the greatest frequency. With the gradual shift from scratch cards for airtime to electronic transfers, many of the airtime 
operators have either switched into the provision of mobile money services or added mobile money services to their existing operations in order to remain in business. Naana (female, aged 28) was operating an airtime business when we first interviewed her in 2012. By 2017, she had added mobile money services to her business, explaining that, 'mobile money business moves faster than airtime business these days.' Similarly, Prince (male, aged 29), was exclusively running an airtime business in 2012 but when we met again in 2017, he had switched into mobile money services. Several of these young people had improvised by creatively switching into mobile money in order to stay in business.

Many of the young entrepreneurs who had operated phone recharging businesses had switched business due to a drop in the demand for their service. There were two key reasons for this falling demand: first, the power supply in Ghana had become much more reliable - at the peak of the power crisis some young people were even using generators to supply power for their mobile phone charging businesses - resulting in there being easy access to power for recharging their phones; second, many people own smartphones for which they carry power banks in order to recharge their phones. Common strategies for former phone recharging business owners include moving into other activities, such as a mobile money transfer business or the selling of phone accessories. Chub (male, aged 33), who had switched from mobile battery recharging into the sale of phone accessories explained how:

Most people are not bringing their phones for recharging as the power situation is good and they are able to charge their phones using power banks. Some people also don't feel comfortable leaving their smart phones with us.

This shows how, coinciding with the increasing use of smartphones, individuals have become more security conscious and have data concerns regarding their phones (Ben-Asher et al., 2011) making them reluctant to leave their phones for recharging in public. Through the switching process, young people engage in bricolage through improvisation to create value for themselves and their businesses in a sector confronted with increasing change.

\section{Diversifying business}

Closely linked to switching is diversification, whereby young people engage in bricolage by improvisation (Di Domenico, Haugh, \& Tracey, 2010) in order to sustain their businesses. In response to changes within the mobile telephony sector, many operators do not depend on a 
single line of business. Their strategy is to engage in bricolage through improvisation by diversifying their business activities in order to survive and potentially expand in the future. As Sack (male, aged 34), a phone dealer, explained, 'You cannot depend on only one business line if you want to survive in future. You must add different products that sell quickly’. Typically, the business lines that are added are also within the mobile telephony sector. For example, the majority of people who were engaged in the sale of airtime scratch cards have diversified their activities by adding mobile money transfer services since they are more profitable; most mobile phone users who rely on the electronic payment system utilise the services of mobile money operators to transfer money into their accounts. Fausty (female, aged 28) recounted how:

I was doing the recharge cards and airtime transfer only but I have added mobile money. As for the mobile money, now it is moving faster than the rest. At first it was credit transfer and airtime that were moving but mobile money has taken over and that is more profitable.

The diversification process is also illustrated by the experiences of Dago (male, aged 32), who was initially just selling airtime:

The electronic system of recharging mobile phones has also brought intense competition as many people would want to recharge online [purchase airtime] and get bonuses. The mobile money services have reduced my customer base and I need to be in business. I've added mobile money services as that is what is moving faster.

Some phone repairers have diversified their business activities by adding the sale of replacement parts, such as batteries, phone screens and screen protectors to their repertoire, in order to boost their income base. These entrepreneurs have noted that there has been an increase in the number of repairers over the past few years resulting in rising competition. This was captured by Boakye (male, aged 30) who asked:

Have you seen these screens? I'm selling them and if people come with faulty screens, I don't have to go elsewhere to buy the screens before replacing it to customers. I use my screens and take the small profit on it. This has kept the business moving. 
The ultimate objective of improvising by diversifying, as exemplified by Boakye, is to move with the times in order to stay in business. Using the strategy of diversifying into more profitable activities within the mobile telephony sector is a creative way of making the most efficient use of the meagre resources at the disposal of the young entrepreneurs (Di Domenico, Haugh, \& Tracey, 2010; Salunke, Weerawardena, \& McColl-Kennedy, 2013). By engaging in these bricolage processes, young people are able to keep moving with the changing times while remaining in business.

It is important to note that not all young people are able to successfully switch and diversify their businesses. Young people who are unable to do so have experienced the greatest challenges in keeping their businesses going over the years. A key challenge is the increasing competition in the sector, which reduces their customer base and future business prospects. This requires continuous improvisation by bringing creativity in their businesses in order to succeed (Di Domenico, Haugh, \& Tracey, 2010; Salunke, Weerawardena, \& McCollKennedy, 2013). Young people who are unable to improvise experience their businesses stagnating. The inability to engage in bricolage to bring about improvements in his business was captured in the narrative of James (aged 38) who deals in airtime at the wholesale level:

With the advent of the electronic system of mobile credit recharging and its numerous attractive bonus packages, the airtime business has slowed down. My profit margin compared to what I was making five years ago has reduced significantly. This has seriously affected me as the business is not moving forward.

James has maintained the same business line since we first met in 2011, demonstrating the impact of not being innovative and moving with the times.

\section{Skills acquisition}

Most young people involved in the mobile phone repair business have picked up the skills of repairing phones through traditional apprenticeship arrangements (see Aryeetey, Doh, \& Andoh, 2013; Gough et al., 2019) under the tutelage of master phone repairers. Many of these master craftsmen were previously engaged in repairing watches and other electronic gadgets. With the advent of the mobile phone and associated decline in the number of people using watches, many of these repairers have moved into the phone repair business where they 
engage in bricolage by 'making do' with the limited resources at their disposal (Baker \& Nelson, 2005). Not only do they engage in bricolage by using their already existing skills from the watch repair business, but the master craftsmen have subsequently trained a number of young people who do not have the means to go through formal training programmes in phone repairs.

Once an apprentice has been accepted by a master repairer, the learning process takes between six months and one year. At the initial stages, the apprentice must run errands ranging from buying repair parts and food for the master. Over time, the apprentice is exposed to the repair process and gradually learns under the guidance of the master repairer until reaching the point where he ${ }^{5}$ is able to handle repairs on his own. As is typical for apprenticeships in Ghana, during this learning period, the apprentice is not paid but receives small allowances and tips from the master repairer (Gough et al., 2019). Michael, a mobile phone repairer (aged 29), explained how through his own ingenuity he managed to save some money even while an apprentice: 'Sometimes, you will go out to buy something and you'll bargain for them to reduce the price. As for that one, the money is yours. It is not for your Master; it is your own money.' Through the skills acquisition process, the young entrepreneurs are thus able to create value from nothing (Baker \& Nelson, 2005; Salunke, Weerawardena, \& McColl-Kennedy, 2013).

In addition, young phone repairers engage in bricolage through improvisation in periodically upgrading their skills in order to keep up with the technological changes in the sector. Upgrading of skills is particularly key for the phone repairers, where advances in technology result in new more sophisticated phones frequently entering the market. To keep themselves abreast of these changes, the repairers spend considerable time on the internet learning about the features of these new phones. The process of acquiring new skills amid continuing technological change was captured by a phone repairer Martins (male, aged 29) as follows:

If you take the iPhones for instance, at first there were only a few models, but now they come in different models. So, the more we get new phones, when you visit the internet you will understand everything. ... This one for instance I was not taught, but when the time came, I did my own research and got to know it.

\footnotetext{
${ }^{5}$ We use the pronoun he here as all those engaged in repairing mobile phones were male.
} 
The repairers reported that they rely on their own ingenuity and efforts in the acquisition of the knowledge and skills needed in repairing mobile phones. There is no avenue for the young entrepreneurs to upgrade their skills, because of which they have to improvise by picking up pieces of information on the internet in order to stay in business.

Having explored the changes in the mobile telephony sector in recent years, and the ways in which those working in the sector have confronted these by engaging in various forms of bricolage to stay in business, we now turn to examine how young entrepreneurs utilise bricolage in mobilising different kinds of resources to sustain and move their businesses into the future.

\section{Mobilising resources for business}

Gaining access to resources for business is challenging, especially for young people running their own businesses in the informal economy (Langevang et al., 2016). Financial institutions are reluctant to lend to informal economy entrepreneurs, especially young people, as they are considered risky (Ghana Trades Union Congress, 2009; Langevang et al., 2016; Nassuna et al. 2016), hence banks and other institutions make it difficult for such individuals to meet their collateral requirements. Loans that are issued are charged high interest rates. ${ }^{6}$ Due to their inability to raise monetary resources through the official financial system, young entrepreneurs within the mobile telephony sector engage in bricolage by mobilising resources through their own initiatives and ingenuity, through improvising, and via their social networks (Mumba, 2016). These resources extend beyond just finance to include information about available spaces to operate from, and ideas for starting and running businesses. This section is divided into two themes: self-support and social networks.

\section{Self-support}

Entrepreneurs draw heavily on their own initiative to start their businesses. The funding for starting and operating small businesses in Ghana, especially those operated by young people, largely comes from their own savings or informal contacts, with very little support from banks and the institutional system (Yankson \& Owusu, 2016). Through self-support and

\footnotetext{
${ }^{6}$ According to the Bank of Ghana, average base rate at end of January 31, 2018 was 25.6 percent compared to 27.6 per cent at end of January 2017
} 
ingenuity, young people mobilise financial resources to maintain and even expand their businesses. The sentiments of a section of young people on how they mobilise financial resources in running and sustaining their businesses are captured below:

I have never gone for a loan. Never! But the little profit I earn is what I use. It is this little profit that I reinvest into the business. (Prince, male, aged 29, mobile money vender)

I raise funds only from my profit. Like I said, I don't get funding from any bank or relative. I rather give to some of my relatives. (Sam, male, aged 26, mobile phone sales)

Who will help you? We own ourselves. As for the bank I don't know if they are there for some of us. (Kobina Baah, male, aged 33, mobile phone repairer)

As all of these young people reported in both the initial and subsequent interviews, they have never received any support from the formal financial system, either from a bank or microfinance institution. The alternative for most young people is to engage in bricolage by gradually mobilising savings from any money they earn or can raise. Through this process, young people are able to make do with the little at hand irrespective of the constraints posed by the financial system (Ciborra, 1996; Baker et al., 2003; Di Domenico, Haugh, \& Tracey, 2010; Duymedjian \& Rüling, 2010; Holt \& Littlewood, 2015). They must mobilise from any meagre resources that come their way, while confronting the challenge of limited institutional support to young people, especially those operating within the informal economy.

The self-support and ingenuity of the young entrepreneurs is not limited to financial resources. Many alluded to engaging in bricolage by relying on their own initiatives with respect to ideas for starting and expanding their businesses. The young people look for any opportunities in the challenging business terrain to start businesses that they think have a future. Moreover, many rarely rely solely on one line of business; while running one enterprise they look out for opportunities to start other business lines alongside. A quote from Innocent (male, aged 32, airtime and mobile money vender) captures this phenomenon: 
Nobody introduced me to this business. It was my own initiative. I first started operating a communication centre [pay phone service], then I started the space-space business alongside selling recharge cards. I look out for every little business opportunity and act on it. I must say that the profit from these small businesses is what I use in expanding the business.

Similarly, Elvis (male, aged 32, mobile phone seller) reported how he slowly managed to expand his business:

I started with keypad phones on my own and gradually the profit you get then you put it down. When you save enough then you go and buy another one. Let's say you sell it and get 50 Ghana [Cedis] and you buy another phone. Gradually the business will be growing, little by little.

From the narratives above, it is clear how young people utilise bricolage by relying on their own initiative and ingenuity (Baker et al., 2003; Di Domenico, Haugh, \& Tracey, 2010) in exploring business avenues to invest in within a difficult and fast changing environment, while ploughing back the little profit they make in order to expand and sustain their business.

\section{Social networks}

Aside relying on ingenuity and self-support, for some of the entrepreneurs, evidence of bricolage could be seen in the form of support from their network of relations (social capital), which is crucial in the resource mobilisation process. This network of relations comprises primarily of support mobilised from friends and family members for business purposes. Over two-thirds of all the young entrepreneurs interviewed alluded to receiving some support from family relations and friends. For most young people, the institutional setting places a constraint on their ability to mobilise resources for their businesses due to difficult collateral requirements and high interest rates. They respond by engaging in bricolage through the utilisation of bottom-up approaches of mobilising resources from friends and family relations. This support comes in various forms such as finance, information, advice, and access to space for business, as captured in the following statements from two young entrepreneurs:

I started this business [airtime] at a corner under a staircase in Madina. But through a conversation with a friend, I got to know that the owner for my current shop was 
looking for someone to rent the shop because the previous tenant was not paying her bills regularly. So, I quickly went to talk to the shop owner, paid some money to him and he rented the shop to me. (Kelly, female, aged 34, mobile money and airtime)

A friend introduced me to the business. From the beginning I wasn't comfortable with it because [I went] right from SHS ${ }^{7}$ to the street. Sometimes you will be meeting a lot of friends and they will be asking so many questions, but I had to do it as there were limited opportunities. (Elvis, male, aged 32, phone sales)

Although Elvis mobilised ideas for his business through friends, as he indicates, some of his friends tease him because after leaving high school he started a business on the street, indicating the double-edged sword of people's networks of relations. Elvis was hesitant in going ahead with his business but had no other option as there is limited paid employment, especially in the formal sector. Through their friends and family relations, young people are able to mobilise various kinds of resources in a business environment that offers very little in terms of support to young informal economy operators, thus, demonstrating the value of social capital for generating resources for small and informal businesses (Fuller, 2003; Mumba, 2016).

Access to business operating space has become extremely difficult for young people in the informal economy. This has been worsened by concerns regarding the influx of foreign nationals, primarily Chinese and Nigerians (Giese, 2017; Bosiakoh, 2017), who have ventured into the retail trade, despite this being against the law in the case of small businesses. ${ }^{8}$ The influx of foreign nationals has contributed to increases in rental values, with some landlords preferring to rent out their stores or business spaces to foreigners who are able to pay more than Ghanaians. In an attempt to overcome the lack of business operating space, many young people, especially those engaged in the sale of mobile phones, accessories and airtime, start their businesses by selling out of their hands moving from one location to another or position themselves at strategic spaces from where they sell their goods to passersby. Selling by hand amidst densely occupied spaces demonstrates how young people engage in bricolage by making do with the limited resources at hand. When we met Elvis (male, aged

\footnotetext{
${ }^{7}$ SHS is an acronym for Senior High School.

8 The Ghana Investment Promotion Council (GIPC) Act, 2013 (Act 865) forbids foreigners from engaging in lower echelons of retail trade in Ghana.
} 
32 ) in 2012, he did not have a fixed location from where he sold mobile phones but roamed around at Madina Zongo junction. He narrated how he has mobilised resources over the years to expand his business:

I started my business in my hands. I didn't have anywhere to sell, and I couldn't afford to rent a place at the time. What I did was to hold the phones in my hands and approach people and sell to them by the roadside. Gradually, the small profit I was making was what I reinvested into the business. I got the capital from the little profit I raised, and I used it to buy one or three phones and I had to make my own table on which to sell the phones. Getting a place wasn't easy from the beginning, but I met a friend who has a store, so I approached him to position my table in front of his store and he allowed me.

Elvis currently operates his business in a glass box in front of his friend's store at Madina Zongo junction. His case shows how young people use their social networks to confront the challenge of gaining access to business operating space in Accra. Over time, some are able to creatively mobilise financial resources by saving from their profits to rent space elsewhere for their businesses. Through this gradual process of bottom-up resource mobilisation and conscious savings, young people have been able to expand their businesses. The attempts to resolve the space challenge demonstrate how young people make do with the little at hand by creating value from nothing (Duymedjian \& Rüling, 2010; Holt \& Littlewood, 2015).

Key to sustaining social networks and accessing embedded resources is trust building. The young people creatively utilise this avenue by mobilising resources to sustain their businesses. In order to overcome the challenge of limited access to credit, some young people arrange with specific suppliers who provide them with goods on credit; after selling these goods they reimburse the suppliers. The young entrepreneurs described this avenue as a less expensive means of accessing credit without paying the exorbitant interest rates and charges of banks and micro-finance institutions. The success of this arrangement, however, largely depends on the trust the young people have built with suppliers over time, as captured by Peter (aged 25), an airtime dealer located in Madina:

For the airtime, I have an agent who supplies me on credit. Because of the good relationship I have with him, sometimes he can even call me to ask if I need credit, 
and if I say yes, he sends it to me and comes for the money or I go give it to him later.

For young people who make repayments regularly, suppliers are willing to continue to honour the credit arrangements as they are confident that repayments will be made. Through this process, the young entrepreneurs make do by creatively mobilising interest free resources from non-conventional sources that they use in running and sustaining their businesses.

As well as gaining the trust of suppliers, young entrepreneurs try to build up a loyal customer base. Strategies to do this include offering good customer service and selling high quality products. John (male, aged 30), who was selling phone accessories, explained how he treated his customers:

For some people it depends on the way you talk to them as well as the quality of the product you sell. This will make them buy your product and when they leave, they will tell others to come and buy. Sometimes people come around to say, 'Oh it is someone who gave me the direction'. We are honest people sitting here.

Similarly, Baaba (female, aged 30) who was selling mobile phones emphasized the importance of customer service:

Oh, you see it is about the way you approach and talk to your customers. Whether good or bad, right or wrong, the way you will relate with the customer is what will motivate the customer to purchase your phone and come back next time or recommend you to another person. If people come to you and you don't treat them well, they will not return to you again.

These narratives show how young people make do by utilising their ingenuity to establish relationships based on trust with their customers in order to survive in the competitive business environment in which they find themselves. They build this trust through selling quality products and offering excellent customer service, all of which bring about recommendations from customers. Consequently, most young people through their ingenuity and innovativeness manage to stay in business (Wildman, 2005). Having demonstrated how 
young entrepreneurs engage in bricolage to mobilise resources for their businesses, we now turn our attention to the role of bricolage processes in envisioning their possible futures.

\section{Bricolage and possible futures of entrepreneurs in the mobile telephony sector}

Many of the young entrepreneurs in the mobile telephony sector were observed to be engaged in bricolage through improvisation, whereby they switch businesses, diversify and learn new skills in order to keep their enterprises running. This raises some key questions regarding their futures: How do these bricolage activities affect the young entrepreneurs' prospects? What futures do young people in the mobile telephony sector envision for themselves? What power do these young people have to shape their own futures? These questions will be discussed in turn here.

First, having to engage in bricolage clearly affects the ways in which young entrepreneurs run their businesses and has implications for their future. Having to rely on self-funding, support from their social networks and ingenuity to mobilise financial resources, all of which are insecure sources, results in the entrepreneurs being vulnerable financially. Mobilising resources informally has long been noted to affect future growth prospects of businesses (Cressy, 1995) and is not exclusive to the mobile telephony sector or Ghana. As Gough, Chigunta and Langevang (2016) have shown in a Zambian context, young entrepreneurs operate in very insecure environments where the death of a sponsor, for example, can signify the end of a business. Obtaining funding from formal sources, such as banks, however, would not necessarily be advantageous for the young entrepreneurs. Mobilising funds informally shields business operators from the high interest rates charged by the formal financial system. Afutu-Kotey (2013) shows how young entrepreneurs who have obtained funding from banks or microfinance institutions have struggled to pay these high interest rates, resulting in some businesses collapsing. Despite the insecurity, raising finance through informal sources by engaging in bricolage can be advantageous for the future of young entrepreneurs' businesses. It can also increase the entrepreneurs' personal control over their enterprises, which has been shown to ensure brighter prospects (Fuller, 2003). Having a good understanding of the potential sources of cash and knowing when, how and which source to approach, is crucial for the success of businesses (Henry, 2016).

In Ghana, and elsewhere in Sub-Saharan Africa, although many people start businesses, there is a high failure rate; the discontinuance rate in Ghana for men is 31.6 percent and is even 
higher for women at 45.1 percent (Langevang et al. 2015). The main reasons these businesses fail are accessing finance, lack of profitability, and personal reasons (Langevang et al. 2015). The fact that most of the young people interviewed in 2012 were still operating their businesses five years later, reflects their ability to engage in bricolage through a continued process of improvisation, ingenuity, drawing on social capital and personal commitment. It also demonstrates the attractiveness and continued importance of the rapidly changing mobile telephony sector, which augers well for the future of the young entrepreneurs.

Second, we turn to consider the futures young people in the mobile telephony sector envision for themselves. Most young people operating mobile telephony businesses plan to stay within the sector, which is markedly different from other business types that typically young people move into and out of 'trying their luck' (Langevang, 2008; Esson, 2015). This practice of seizing opportunities as they unfold and rapidly changing business sectors has been aptly coined 'zigzagging' (Gough, Chigunta, \& Langevang, 2016; Jones, 2010). The mobile telephony sector differs as it is seen by young people as being profitable with a promising future. Moreover, a key motivation for entering the sector is the passion that young people have for mobile phones (Afutu-Kotey, Gough \& Owusu, 2017), which results in them wanting to stay in mobile telephony even if they switch businesses and diversify within the sector. As Fuller (2003) has argued, personal commitment can transcend economic constraints for small (including informal) businesses. Most young people interviewed expressed growth aspirations including acquiring bigger premises, expanding into wholesale, opening new branches, purchasing new equipment, and acquiring new skills (Afutu-Kotey, Gough, \& Owusu, 2017). Some are successful in achieving these aspirations whereas for others, although their aspirations remain elusive, they tend to stay in the sector.

A typical case is Kwesi, a young man aged 29 who was dealing in phone accessories when we first interviewed him in 2012. His vision at that time was to expand his business into wholesale phone accessories. Five years later, Kwesi had expanded his business and was operating from a bigger glass cabinet but he had not managed to move into wholesale due to lack of financial capital. He was continuing to engage in bricolage in order to try to achieve his ambition to travel outside the country and bring back phone accessories to sell wholesale. Similarly, Okai (male, aged 33, phone repairer), whose plans have not changed since 2012, foresees himself in the future expanding his business into training young people in phone repairs: 
I see myself establishing a mobile phone repair training school for the youth in future. This is the project I want to do, and I think I will need support to get a big place to train the youth... I am thinking about what I can do to help them.

In both cases, these young men have high ambitions for the future but their lack of access to any formal support means they have no clear pathway to achieve their goals. Thus, although engaging in bricolage has enabled them to stay in business, it has not yet provided them with a means to expand their small informal businesses.

It is important to recognise, however, that not all the young people interviewed envisioned their futures in the mobile telephony business, especially those selling airtime who saw it as a quick way of earning money. A typical example is Efe (female, aged 25) who was selling airtime in 2012 when we first interviewed her. She noted at the time that, 'I don't see my future in this business.' Her aim was to save money in order to go back to school. When we interviewed Efe in 2017, her situation was unchanged. She was still running her airtime business because she aspires to go back to school but her chances of doing so are tied to the prospects of the business going well.

Third, we address the interesting but challenging issue of the power these young people have, to shape their own futures. As this study has shown, young people clearly have a degree of agency, deciding which businesses to enter and engaging in bricolage to try to grow their businesses. They face restrictions though at every turn having to rely on the limited resources they can raise informally and having to be ingenious to find ways of learning new skills to run their businesses. Inevitably, young people are constrained by the neoliberal economic environment they are working within. As Carmody (2012:11) has argued, 'Africa is incorporated into the global technological revolution primarily in a dependent manner - as an importer, rather than producer of technology'. Consequently, mobile phones are being absorbed into economic structures but are not transforming them, rather they reinforce inequitable structures and poverty (Carmody, 2012). Thus, while the mobile telephony sector enables some young people to run profitable businesses, and the sector holds much more promise than many others, young entrepreneurs are heavily restrained by national and global economic processes. 


\section{Conclusions}

This paper contributes to our understanding of how informal economy entrepreneurs in a global South context engage in bricolage in order to establish and run businesses in resource constrained environments. Young entrepreneurs operating in the rapidly changing, technologically driven mobile telephony sector in Ghana utilise bricolage in various ways to mobilise resources that enable them to set up and sustain businesses. Bricolage as improvisation (Di Domenico, Haugh, \& Tracey, 2010) is a key process whereby the young entrepreneurs creatively utilise strategies, such as switching from one business to another or diversifying their business activities within the same sector, as they perceive better ways of increasing their incomes within the continually changing sector. A core example of this is young entrepreneurs who had innovatively established mobile phone recharging businesses in busy marketplaces and transport hubs, moving into other sectors, such as mobile money transfer or sale of mobile phone accessories after the electricity supply improved making their initial businesses redundant.

Another key bricolage process observed is making do (Baker \& Nelson, 2005). Young people were found to utilise pre-existing skills gained from other activities and use them in the mobile telephony sector. Here those engaged in mobile phone repairs stand out for the way in which they use skills gained in learning to repair watches to instead repair mobile phones, after the demand for the latter came to far exceed the former. The young entrepreneurs do not only 'make do' though, they also must be innovative to acquire new skills, most of which they gain from the internet, as mobile phone technology develops. Bricolage as refusing to be constrained (Salunke, Weerawardena, \& McColl-Kennedy, 2013) is clearly evident throughout the mobile telephony sector in Ghana. Despite the challenges they face, the young entrepreneurs rarely admit defeat, drawing on social networks of people they trust, especially friendship groups, to mobilise resources (including financial and accessing business space) to run and develop their businesses. The sustainability of these businesses is important for the individual entrepreneurs, their families and their futures (Fuller, 2003).

The paper has also added valuable knowledge concerning the trajectories of young people entering the mobile telephony sector. Unlike sectors, such as dressmaking and cane weaving, where the technologies have changed little over the years and the trades are seen as being for 'school dropouts' (Gough et al., 2019), or other sectors that young people enter and quickly leave again 'trying their luck' (Langevang, 2008; Esson, 2015), mobile telephony is seen as a desirable sector which, for those able to engage in bricolage, it can provide a sustainable 
livelihood. Where other studies have illustrated the way in which young people 'zigzag' between sectors, (Gough, Chigunta, \& Langevang, 2016; Jones, 2010) by adopting a longitudinal approach, this paper shows that the majority of young people who establish a mobile telephony related business chose to enter and stay within the sector. This is even more remarkable given the pace of technological change affecting the sector; for example, within a five-year period, a whole activity - the airtime business - was totally transformed with the introduction of electronic payment systems. Although technological change affects all informal economy operators, the rate and magnitude of change is greater within the mobile telephony sector compared with other sectors. In settings where resource availability is especially limited for young people (Gough \& Langevang, 2016), their commitment to remain in the mobile telephony sector is an encouraging finding.

The mobile telephony sector will undoubtedly continue to be seen by young people in the global South as an attractive sector within which to set up a business. As forthcoming technological developments affect entrepreneurs operating within the sector, they will have to maintain their creative strategizing in order to stay in business. The future for young entrepreneurs in the mobile telephony sector looks promising as they have demonstrated an ability to creatively utilise numerous strategies in confronting its rapidly changing nature. Despite many young entrepreneurs having demonstrated an ability to survive through engaging in bricolage, however, it is important that they are not just expected to cope on their own (Gough \& Langevang, 2016). A supportive institutional framework, including affordable credit facilities and training in small business management, from governmental agencies, civil society and interested private organisations, would help young entrepreneurs propel their businesses into the future.

\section{References}

Afutu-Kotey, R. L. (2013). Youth livelihoods and entrepreneurship in the mobile telephony sector in the Greater Accra Metropolitan Area. (Unpublished doctoral thesis). University of Ghana, Legon-Accra, Ghana.

Afutu-Kotey, R. L. (2016). Young entrepreneurs in the mobile telephony sector in Ghana. In K. V. Gough and T. Langevang (Eds.), Young Entrepreneurs in Sub-Saharan Africa (pp. 167-180). New York \& London: Routledge. 
Afutu-Kotey, R.L., Gough, K.V. \& Owusu, G. (2017). Young entrepreneurs in the mobile telephony sector in Ghana: from necessities to aspirations, Journal of African Business, $18(4), 476-491$.

Afutu-Kotey, R. L., Gough, K. V., \& Yankson, P. W. (2017). Transitions to adulthood among young entrepreneurs in the informal mobile telephony sector in Accra, Ghana. Geoforum, 85, 290-298.

Aker, J. C., \& Mbiti, I. M. (2010). Mobile phones and economic development in Africa. Journal of Economic Perspectives, 24(3), 207-32.

Amankwaa, E. F. (2017). Water and Electricity Access for Home-based Enterprises and Poverty Reduction in the Greater Accra Metropolitan Area (GAMA). Ghana: University of Ghana (Unpublished PhD thesis, 2017).

An, W., Zhao, X., Cao, Z., Zhang, J., \& Liu, H. (2018). How bricolage drives corporate entrepreneurship: the roles of opportunity identification and learning orientation. Journal of Product Innovation Management, 35(1), 49-65.

Aryeetey, E., Doh, D., \& Andoh, P. (2013). Choosing an apprenticeship: skills preferences amongst the youth. International Development Planning Review, 35(2), 135-153.

Asongu, S. A., \& Nwachukwu, J. C. (2016). The role of governance in mobile phones for inclusive human development in Sub-Saharan Africa. Technovation, 55, 1-13.

Baker, T., Miner, A. S., \& Eesley, D. T. (2003). Improvising firms: Bricolage, account giving and improvisational competencies in the founding process. Research policy, 32(2), 255-276.

Baker, T., \& Nelson, R. E. (2005). Creating something from nothing: Resource construction through entrepreneurial bricolage. Administrative science quarterly, 50(3), 329-366.

Ben-Asher, N., Kirschnick, N., Sieger, H., Meyer, J., Ben-Oved, A., \& Möller, S. (2011, August). On the need for different security methods on mobile phones. In Proceedings of the 13th International Conference on Human Computer Interaction with Mobile Devices and Services (pp. 465-473). ACM.

Berchicci, L., \& Hulsink, W. (2006). Of Bikes and Men: Innovation patterns and strategic entrepreneurship in the human-powered vehicle sector. Strategic Entrepreneurship: The Role of Networking, Vrije Universiteit Amsterdam.

Bosiakoh, T. A. (2017, June). Nigerian Immigrant Entrepreneurs in Contemporary Ghana: Insights on Locational/Sectoral Niches and Inter-Generational (Dis) Continuities. In Urban Forum 28 (2), 143-163.

Carmody, P. (2012). The informationalization of poverty in Africa? Mobile phones and economic structure. Information Technologies \& International Development, 8(3), 8(3), 1-17.

Carstensen, M. B. (2011). Paradigm man vs. the bricoleur: bricolage as an alternative vision of agency in ideational change. European political science review, 3(1), 147-167. 
Castells, M., \& Portes, A. (1989). World underneath: The origins, dynamics, and effects of the informal economy. In A. Portes, M. Castells and L. A. Benton, The informal economy: Studies in advanced and less developed countries (pp. 11-37). Baltimore: John Hopkins University Press.

Ciborra, C. U. (1996). The platform organization: Recombining strategies, structures, and surprises. Organization science, 7(2), 103-118.

Cressy, R. (1995). Business borrowing and control: A theory of entrepreneurial types. Small business economics, 7(4), 291-300.

Desa, G., \& Basu, S. (2013). Optimization or bricolage? Overcoming resource constraints in global social entrepreneurship. Strategic Entrepreneurship Journal, 7(1), 26-49.

Di Domenico, M., Haugh, H., \& Tracey, P. (2010). Social bricolage: Theorizing social value creation in social enterprises. Entrepreneurship theory and practice, 34(4), 681-703.

Dolan, C. (2012). The new face of development: The 'bottom of the pyramid' entrepreneurs. Anthropology Today, 28(4), 3-7.

Donner, J. (2015). After access: Inclusion, development, and a more mobile Internet. MIT Press.

Duymedjian, R., \& Rüling, C. C. (2010). Towards a foundation of bricolage in organization and management theory. Organization Studies, 31(2), 133-151.

Eshun, M. E. and Amoako-Tuffour, J. (2016). A review of the trends in Ghana's power sector. Energy, Sustainability and Society, 6(9), 1-9.

Esson, J. (2015). You have to try your luck!: male Ghanaian youth and the uncertainty of football migration. Environment and Planning A 46(6), 1383-1397.

Fuller, T. (2003). If you wanted to know the future of small business what questions would you ask? Futures, 35(4), 305-321.

Garud, R., \& Karnøe, P. (2003). Bricolage versus breakthrough: distributed and embedded agency in technology entrepreneurship. Research policy, 32(2), 277-300.

Ghana Trades Union Congress (2009). The Labor Market in Ghana: A Descriptive Analysis of the Labour Market Component of the Ghana Living Standards Survey (V), Accra.

Gibbert, M., Hoegl, M. \& L. Välikangas L. (2007). In praise of resource constraints. MIT Sloan Management Review 48 (3): 15-17.

Giese, K. (2017). Chinese Traders in Ghana: The Liminality Trap, and Challenges for Ethnic Formation and Integration. In Contemporary Chinese Diasporas (pp. 53-77). Palgrave, Singapore. 
Gough, K.V., Chigunta, F. \& Langevang, T. (2016). Expanding the scales and domains of (in)security: Youth employment in urban Zambia, Environment and Planning A, 48(2): 348366.

Gough, K. V., \& Langevang, T. (Eds.). (2016). Young Entrepreneurs in Sub-Saharan Africa. Routledge.

Gough, K.V., Langevang, T., \& Owusu, G. (2013). Youth employment in a globalising world. International Development Planning Review, 35(2), 91-102.

Gough, K.V., Langevang, T., Yankson, P.W.K. and Owusu, G. (2019). Shaping geographies of informal education: a global South perspective, Annals of the American Association of Geographers (in press)

Gurtoo, A., \& Williams, C. C. (2009). Entrepreneurship and the informal sector: some lessons from India. The International Journal of Entrepreneurship and Innovation, 10(1), 5562.

Hajdu, F., Ansell, N., Robson, E., \& van Blerk, L. (2013). Rural young people's opportunities for employment and entrepreneurship in globalised southern Africa: the limitations of targeting policies. International Development Planning Review, 35(2), 155-174.

Hampshire, K., Porter, G., Owusu, S. A., Mariwah, S., Abane, A., Robson, E., \& Milner, J. (2015). Informal m-health: How are young people using mobile phones to bridge healthcare gaps in Sub-Saharan Africa?. Social Science \& Medicine, 142, 90-99.

Henry, G. F. (2016). Funding innovation: Moving the business forward. Surgery, 160(5), $1135-1138$.

Hoffner, C. A., Lee, S., \& Park, S. J. (2016). “I miss my mobile phone!”: Self-expansion via mobile phone and responses to phone loss. New Media \& Society, 18(11), 2452-2468.

Holt, D., \& Littlewood, D. (2017). Waste livelihoods amongst the poor-Through the lens of bricolage. Business Strategy and the Environment, 26(2), 253-264.

Jeffrey, C., \& Young, S. (2014). Jugād: Youth and enterprise in India. Annals of the Association of American Geographers, 104(1), 182-195.

Jones, J.L. (2010). 'Nothing is straight in Zimbabwe': The rise of the Kikiya-kiya economy 2000-2008. Journal of Southern Africa Studies, 36(2), 285-289.

Komunte, M. (2015). Usage of mobile technology in women entrepreneurs: A case study of Uganda. The African Journal of Information Systems, 7(3), 3.

Kristensen, S., \& Birch-Thomsen, T. (2013). Should I stay or should I go? Rural youth employment in Uganda and Zambia. International Development Planning Review, 35(2), 175-201. 
Kuznekoff, J. H., Munz, S., \& Titsworth, S. (2015). Mobile phones in the classroom: Examining the effects of texting, Twitter, and message content on student learning. Communication Education, 64(3), 344-365.

Kuznekoff, J. H., \& Titsworth, S. (2013). The impact of mobile phone usage on student learning. Communication Education, 62(3), 233-252.

Langevang, T. (2008). 'We are managing!' Uncertain paths to respectable adulthoods in Accra, Ghana, Geoforum 39(6): 2039-2047.

Langevang, T. (2016). Youth Entrepreneurship and Socioeconomic Change in Urban Ghana. Geographies of Global Issues: Change and Threat, 59-78.

Langevang, T., Gough, K. V., \& Namatovu, R. (2016). Youth entrepreneurship in Kampala: managing scarce resources in a challenging environment. In K. V. Gough and T. Langevang (Eds.), Young Entrepreneurs in Sub-Saharan Africa (pp. 80-93). New York \& London: Routledge.

Langevang, T., \& Namatovu, R. (2019). Social bricolage in the aftermath of war. Entrepreneurship \& Regional Development, DOI: 10.1080/08985626.2019.1595743

Langevang, T., Namatovu, R., \& Dawa, S. (2012). Beyond necessity and opportunity entrepreneurship: Motivations and aspirations of young entrepreneurs in Uganda. International Development Planning Review, 34(4), 439-460. Langevang, T., Gough, K.V., Yankson, P.W.K., \& Owusu, G. (2015). Bounded entrepreneurial vitality: the mixed embeddedness of female entrepreneurship, Economic Geography, 91(4): 449-473.

Lanzara, G. F. (1999). Between transient constructs and persistent structures: designing systems in action. The Journal of Strategic Information Systems, 8(4), 331-349.

Lévi-Strauss, C. (1967). The Savage Mind. Chicago. University of Chicago Press.

Ligthelm, A. A. (2010). Entrepreneurship and small business sustainability. Southern African Business Review, 14(3).

Linna, P. (2013). Bricolage as a means of innovating in a resource-scarce environment: A study of innovator-entrepreneurs at the BOP. Journal of Developmental Entrepreneurship, 18(03), 1350015.

Meschtscherjakov, A., Wilfinger, D., \& Tscheligi, M. (2014, April). Mobile attachment causes and consequences for emotional bonding with mobile phones. In Proceedings of the SIGCHI Conference on Human Factors in Computing Systems (pp. 2317-2326). ACM.

Mumba, M. H. (2016). Social capital among young entrepreneurs in Zambia. In K. V. Gough and T. Langevang (Eds.), Young Entrepreneurs in Sub-Saharan Africa (pp. 225-236). New York \& London: Routledge. 
National Communications Authority (NCA), (2018). MNOs Voice Subscription for

December 2018. NCA, Accra. Retrieved from https://www.nca.org.gh/assets/Uploads/VoiceOct-Dec-2018.pdf.

Nassuna, A. N., Jeppesen, S., \& Balunywa, W. (2016). Innovative approaches by Ugandan microfinance institutions to reach out to young entrepreneurs. In K. V. Gough and T.

Langevang (Eds.), Young Entrepreneurs in Sub-Saharan Africa (pp. 237-247). New York \& London: Routled

Porter, G., Hampshire, K., Abane, A., Munthali, A., Robson, E., Mashiri, M., \& Tanle, A. (2012). Youth, mobility and mobile phones in Africa: findings from a three-country study. Information Technology for Development, 18(2), 145-162.

Porter, G. (2015). Mobile phones, mobility practices, and transport organization in SubSaharan Africa. Mobility in history, 6(1), 81-88.

Porter, G., Hampshire, K., Milner, J., Munthali, A., Robson, E., De Lannoy, A., \& Abane, A. (2016). Mobile Phones and education in Sub-Saharan Africa: from youth practice to public policy. Journal of International Development, 28(1), 22-39.

Randerson, K., Dossena, G., \& Fayolle, A. (2016). The futures of family business: family entrepreneurship. Futures, (75), 36-43.

Ray, G., Barney, J. B., \& Muhanna, W. A. (2004). Capabilities, business processes, and competitive advantage: choosing the dependent variable in empirical tests of the resourcebased view. Strategic management journal, 25(1), 23-37.

de Reuver, M., Bouwman, H., Prieto, G., \& Visser, A. (2011). Governance of flexible mobile service platforms. Futures, 43(9), 979-985.

Salunke, S., Weerawardena, J., \& McColl-Kennedy, J. R. (2013). Competing through service innovation: The role of bricolage and entrepreneurship in project-oriented firms. Journal of Business Research, 66(8), 1085-1097.

Senyard, J., Baker, T., Steffens, P., \& Davidsson, P. (2014). Bricolage as a path to innovativeness for resource-constrained new firms. Journal of Product Innovation Management, 31(2), 211-230.

de Soto, H. (2000). The mystery of capital: Why capitalism triumphs in the West and fails everywhere else. Basic Civitas Books, (Chapter 1).

Steyaert, C., \& Katz, J. (2004). Reclaiming the space of entrepreneurship in society: geographical, discursive and social dimensions. Entrepreneurship \& regional development, 16(3), 179-196.

Thorsen, D. (2013). Weaving in and out of employment and self-employment: young rural migrants in the informal economy of Ouagadougou. International Development Planning Review, 35(2), 203-218. 
Vincent, J. (2006). Emotional attachment and mobile phones. Knowledge, Technology \& Policy, 19(1), 39-44.

Weick, K. E. (1993). Organizational redesign as improvisation. Organizational change and redesign: Ideas and insights for improving performance, 346, 379.

Witell, L., Gebauer, H., Jaakkola, E., Hammedi, W., Patricio, L., \& Perks, H. (2017). A bricolage perspective on service innovation. Journal of Business Research, 79, 290-298. Wildman, P. (2007). How futuring bush mechanics seek to transform the world. Futures, $39(5), 569-582$.

Yankson, P. W.K., \& Owusu, G. Prospects and challenges of youth entrepreneurship in Nima-Maamobi, a low-income neighbourhood of Accra. In K. V. Gough and T. Langevang (Eds.), Young Entrepreneurs in Sub-Saharan Africa (pp. 94-108). New York \& London: Routledge. 